\title{
ASSESSMENT OF THE EFFECTS OF LAND USE SCENARIOS ON WATERSHED SURFACE RUNOFF USING HYDROLOGICAL MODELLING
}

\author{
AGHAKHANI, M. ${ }^{1}-$ NASRABADI, T. ${ }^{2 *}-$ VAFAEINEJAD, A. ${ }^{3}$ \\ ${ }^{I}$ Department of Environment Management, Faculty of Natural Resources and Environment, \\ Science and Research Branch, Islamic Azad University, Tehran, Iran \\ ${ }^{2}$ Department of Environmental Planning, Management, and Education, University of Tehran, \\ Tehran, Iran \\ ${ }^{3}$ Faculty of Civil, Water and Environmental Engineering, Shahid Beheshti University, \\ Tehran, Iran \\ *Corresponding author \\ e-mail: tnasrabadi@ut.ac.ir; phone: +98-21-6111-3586 \\ (Received $3^{\text {rd }}$ Jan 2018; accepted $26^{\text {th }}$ Mar 2018)
}

\begin{abstract}
To manage watersheds, simulations of hydrological phenomena are very important. This paper investigates hydrological modelling of Taleqan basin in Iran, and studies the effects of land use scenarios on the model runoff using Soil and Water Assessment Tool (SWAT). For this purpose, hydrometeorological data, soil map, land use maps, and digital elevation model of the area were prepared and used for model parameters' sensitivity analysis, model calibration, and validation. Sensitivity analysis was performed using SUFI-2 algorithm. Model performance was evaluated by using time series visual comparison plots and statistical indicators of Nash-Sutcliffe (NS) and the coefficient of determination $\left(\mathrm{R}^{2}\right)$. It was shown that the model has high potential to predict monthly runoff. Then, the effects of land use changes on surface runoff in the basin were studied. For this purpose, practicable land use options in the watershed such as agroforestry, afforestation, expansion of agricultural land, and agriculture on terrace were considered. Hence, various management scenarios resulted from combinations of land use activities. They were applied to the calibrated model, and their effects on surface runoff were studied. The results show that management scenarios may have significant effects on runoff control.
\end{abstract}

Keywords: hydrological simulation, land use change, management scenario, model calibration, sensitivity analysis, SWAT

\section{Introduction}

Surface runoff in a watershed is a major issue in hydrological watershed studies, because most hydrological processes are associated with it directly or indirectly and are somehow affected by it. Understanding hydrological processes and their simulations in a watershed scale and predicting changes of these processes in the future have been perpetual challenges for hydrologists.

Thus, hydrological models are widely used by managers and hydrologists as a tool for understanding natural and human activities affecting watershed hydrology and its planning and management in recent years (Ouyang et al., 2014). These models can provide a precise scientific framework for analysing the water movement in the watershed, and can create a reliable database on the system behaviour. Developments of hydrological models largely depend on geographic information system that made it possible to simulate large areas (Afzal et al., 2015; Jung and Kim, 2017). 
Soil and Water Assessment Tool (SWAT) is commonly used for watershed modelling. The good performance of this model to assess the effects of land management practices on water, sediment, and agricultural products in large and complex watersheds with varying soils, land use, various management conditions during different periods of time and topography has been proved (Kim, 2015).

However, along with successful applications of the mentioned models due to some shortcomings, some numerical processing such as parameters calibration and sensitivity analysis are also essential (Romagnoli et al., 2017). Through sensitivity analysis of model parameters, identifying sensitive parameters based on their effects on the output of the model is possible. Identifying sensitive parameters lead to uncertainty reduction and better simulation (Shahoei et al., 2017).

Ghoraba (2015) conducted a study with the aim of watershed modelling in Simly dam, Pakistan. He used SWAT to estimate monthly volume of water entering the reservoir and determined the water balance to help administrators to plan and manage these important water reservoirs.

Vilaysane et al. (2015) studied the feasibility and performance of the SWAT model to predict river flow in the Xedone river basin, in the southern part of Laos.

Gosain et al. (2006) successfully used the SWAT model to predict the impacts of climate changes on river basin hydrology in 12 areas in India.

Setegn et al. (2008) conducted hydrologic modelling of Lake Tana basin and Pereira et al. (2014) studied the effects of deforestation on water balance components in the watershed located in the eastern coast of Brazil using SWAT model. Li et al. (2014) introduced some approaches for evaluating the effects of land use changes and biophysical conditions on the discharge. Santos et al. (2014) conducted a study on the effects of climate change, human interventions, and modelling uncertainties on the estimation of river basin and its components' characteristics.

In this paper, SWAT was used for modelling the basin that is located in the Northwest of Karaj, Alborz Province, Iran. This watershed is one of the most important sources of water supply for the province of Tehran. The main objectives of this study are to simulate surface runoff and identify sensitive hydrological parameters associated with it, and study the effects of different management scenarios on watershed stream flow. Sensitive parameters were determined by applying sensitivity analysis tool using SWAT-CUP software. More sensitivity analysis of the three most sensitive parameters and their effects on the normalized surface runoff changes is performed. The SWAT model was calibrated according to the changes in the values of the sensitive parameters within authorized ranges. Model calibration and validation were done by using SWATCUP software and SUFI2 algorithm. Then, simulation results with measured values of runoff in watershed outlets were compared. Then, the effects of applying different management scenarios on surface runoff were investigated. For this purpose, possible land use options in the watershed such as agroforestry, afforestation, expansion of agricultural land, and agriculture on terrace and their combinations were considered. Therefore, sixteen management scenarios were created. They were applied to the calibrated model, and the results were studied. Considering all possible combinations of management options to obtain all practical solutions could be very interesting not only for experts and decision makers but also for the general public who are following these issues seriously. Modelling these scenarios helps local and national managers to make the best decisions considering efficiency, condition, time, and cost. This may prevent environmental and social impacts, and waste of time and money. 


\section{Study area}

The Taleqan watershed is located on the southern slopes of the Alborz Mountains, at $120 \mathrm{~km}$ northwest of Tehran, Iran. Most of the area is mountainous with steep slopes with annual average precipitation of $632 \mathrm{~mm}$. Annual average temperature is $10.5^{\circ} \mathrm{C}$ and due to Meteorological Organization reports the area prevailing climate type is cold semi-wet. The study area average elevation above sea level is $2735 \mathrm{~m}$. The most precipitation in the region is in the form of snow. Prevailing watershed hydrology system is based on high volume of runoff in the spring due to melting snow and considerable spring rains. Figure 1 shows the location of studied area located in the upstream of Taleqan dam basin, which is located at $36^{\circ} 04^{\prime}$ to $36^{\circ} 21^{\prime}$ of northern latitude and $50^{\circ} 38^{\prime}$ to $51^{\circ} 12^{\prime}$ e eastern longitude. Most land use in this area is pasture. Part of the land is used by irrigated and rain-fed agriculture. Soil of the basin is mainly loamy and silt loamy.

The main gauging station is Gelinak Station. Two other gauging stations, Joestan (middle of the basin) and Gatehdeh (beginning of the basin) stations, were selected to compare the results with the results of the Gelinak findings.

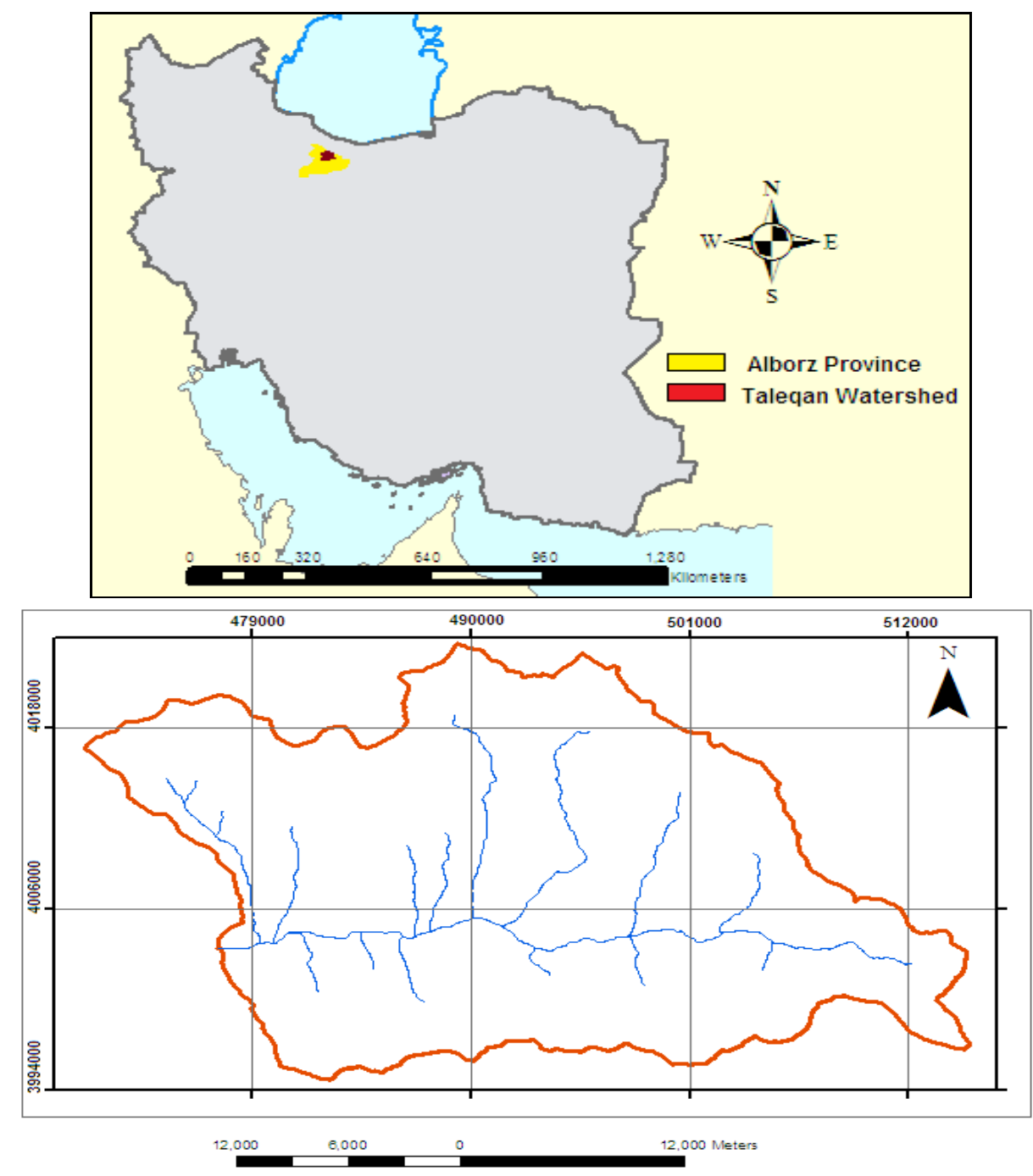

Figure 1. The study area in Alborz Province in Northern Iran and the watershed geographical location 


\section{Materials and methods}

\section{SWAT model and performance evaluation}

In this study, the SWAT model was used to simulate Taleqan watershed hydrological response. SWAT is a semi-distributed and continuous mathematical model that needs various information to run. This model first used in Agricultural Research Service of United States of America, in order to simulate the hydrological processes and predict the impact of management practices on water, sediment and agricultural chemical balance in the large and complex basins. (Azzellino et al., 2015; Bonansea et al., 2015).

In the SWAT model, watershed is divided into subbasins according to DEM input map, which are linked with each other through a network of streams. Then, on the basis of soil and land use in the subbasin, they are divided into smaller units known as HRUs. For each hydrological unit, water and sediment and nutrient and losses cycles are determined and weighted average is calculated for each subbasin. Then, after the accumulation of these quantities of the river network to the basin outlet, the final amount is determined for the basin (Neitsch et al., 2011).

This model allows the modelling of the basin without monitoring data, as well as providing predictive scenarios based on input changes such as land cover, land use operations, climate on nutrient cycling, water quality and quantity for users.

To assess the qualitative and quantitative performance of the model, visual comparison of the time series plots, and statistical indicators such as Nash-Sutcliffe index (NS) and coefficient of determination $\left(\mathrm{R}^{2}\right)$ are addressed (Rahman et al., 2013).

The coefficient of determination $\mathrm{R}^{2}$ is defined as the squared value of the coefficient of correlation. It is calculated as (Eq. 1$)$ :

$$
R^{2}=\left(\frac{\sum_{i=1}^{n}\left(O_{i}-\bar{O}\right)\left(P_{i}-\bar{P}\right)}{\sqrt{\sum_{i=1}^{n}\left(O_{i}-\bar{O}\right)^{2}} \sqrt{\sum_{i=1}^{n}\left(P_{i}-\bar{P}\right)^{2}}}\right)^{2}
$$

with $\mathrm{O}$ and $\mathrm{P}$ indicate observed and predicted values, respectively. $\mathrm{R}^{2}$ can also be expressed as the squared ratio between the covariance and the multiplied standard deviations of the observed and predicted values. (Krause et al., 2005)

The efficiency index NS proposed by Nash and Sutcliffe (1970) is defined as one minus the sum of the absolute squared differences between the predicted and observed values normalized by the variance of the observed values during the period under investigation. It is calculated as (Eq. 2):

$$
N S=1-\frac{\sum_{i=1}^{n}\left(O_{i}-P_{i}\right)^{2}}{\sum_{i=1}^{n}\left(O_{i}-\bar{O}\right)^{2}}
$$

According to performance rating (Cho and Olivera, 2009), Nash-Sutcliffe Efficiency values greater than 0.75 are very good and greater than 0.65 are good. Moreover, the coefficient of determination $\left(\mathrm{R}^{2}\right)$ should be greater than 0.60 (Santhi et al., 2001). 


\section{Model input data}

The input required for the SWAT model includes digital elevation maps, soil data, precipitation data, temperature, meteorology, soil map, and land use map (Arnold et al., 1998; Neitsch et al., 2011).

-Meteorological data: In this study, monthly and daily meteorological data for the 15-year period from 2000 to 2014 were received from the Meteorological Organization and Iran Water Resources Management Company. Daily data include maximum and minimum daily temperature and precipitation. The climatologic stations are listed in Table 1. Moreover, monthly data such as average solar radiation, dew point temperature, and average wind speed of the study area were introduced to the model.

Table 1. Rainfall and temperature stations

\begin{tabular}{c|c|c|c}
\hline Station name & X (UTM) & Y (UTM) & Elevation $(\mathbf{m})$ \\
\hline Hasanjun & 477266 & 4009639 & 1990 \\
Joestan & 490956 & 4004551 & 2220 \\
Nesa & 4900835 & 3998736 & 2310 \\
Dehdar & 505796 & 4004490 & 2400 \\
\hline
\end{tabular}

-Digital Elevation Map (DEM): To prepare basin DEM map, digital topographic map of 2013 with a scale of 1:25000, provided by the National Cartographic Centre, was used.

-Soil map: In order to provide digital soil map and soil information of the basin, soil maps and reports of the Institute of Soil and Water Research (2001) was used.

-Land use map: To prepare the land use map (Fig. 2), interpretation of aerial photographs, updated digital maps of land use by satellite images ETM, and written reports related to Taleqan Basin, provided by Soil and Water Conservation Research Centre, were used.

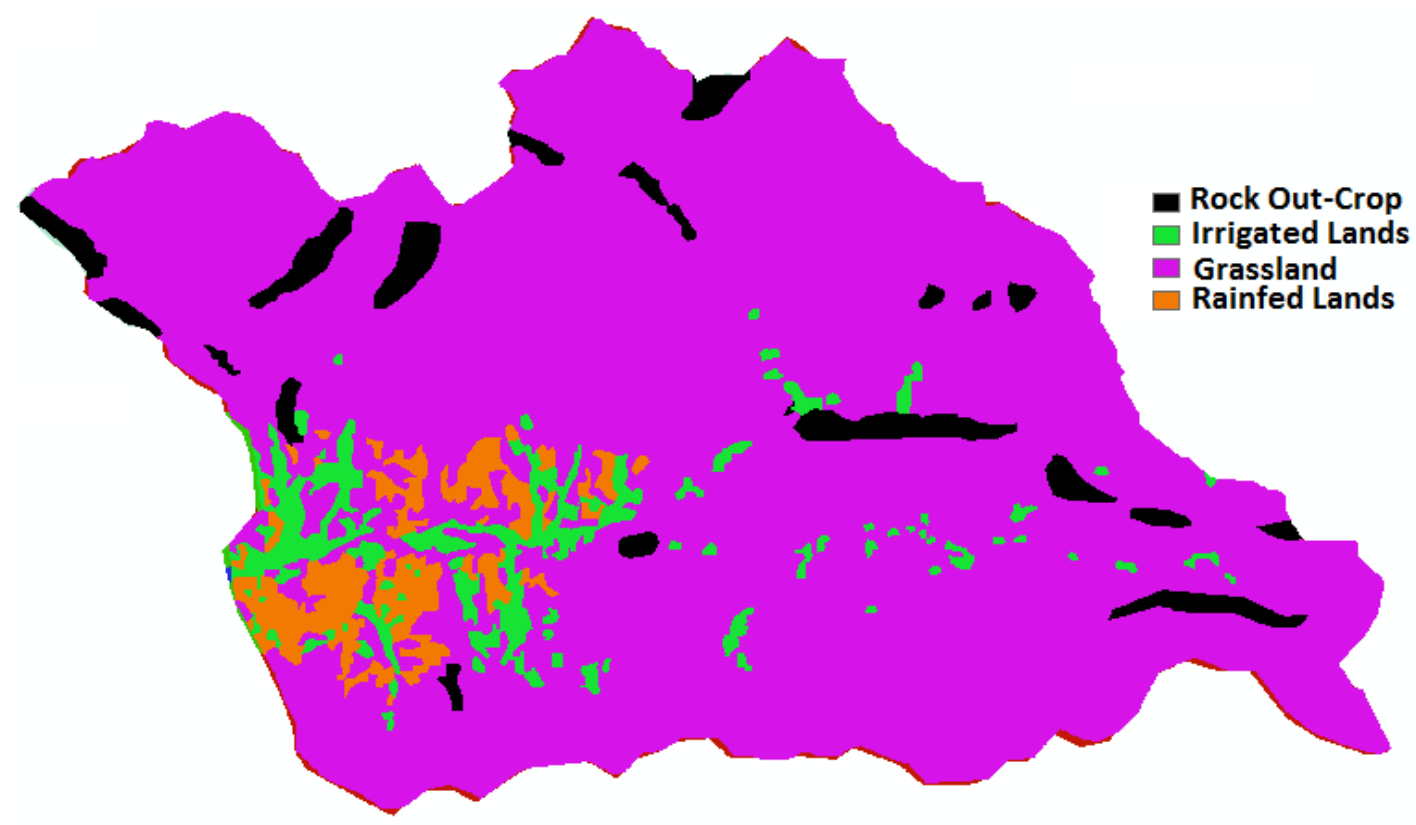

Figure 2. Watershed land use map 


\section{Results and discussion}

\section{Model implementation}

Hence, to run the model, the data layers described in previous sections are presented as input to the model and the basin is divided into 35 subbasins and each subbasin is divided into hydrological response units (HRU). Figure 3 shows the study area subbasins, stream flow, weather stations, and hydrometric stations.

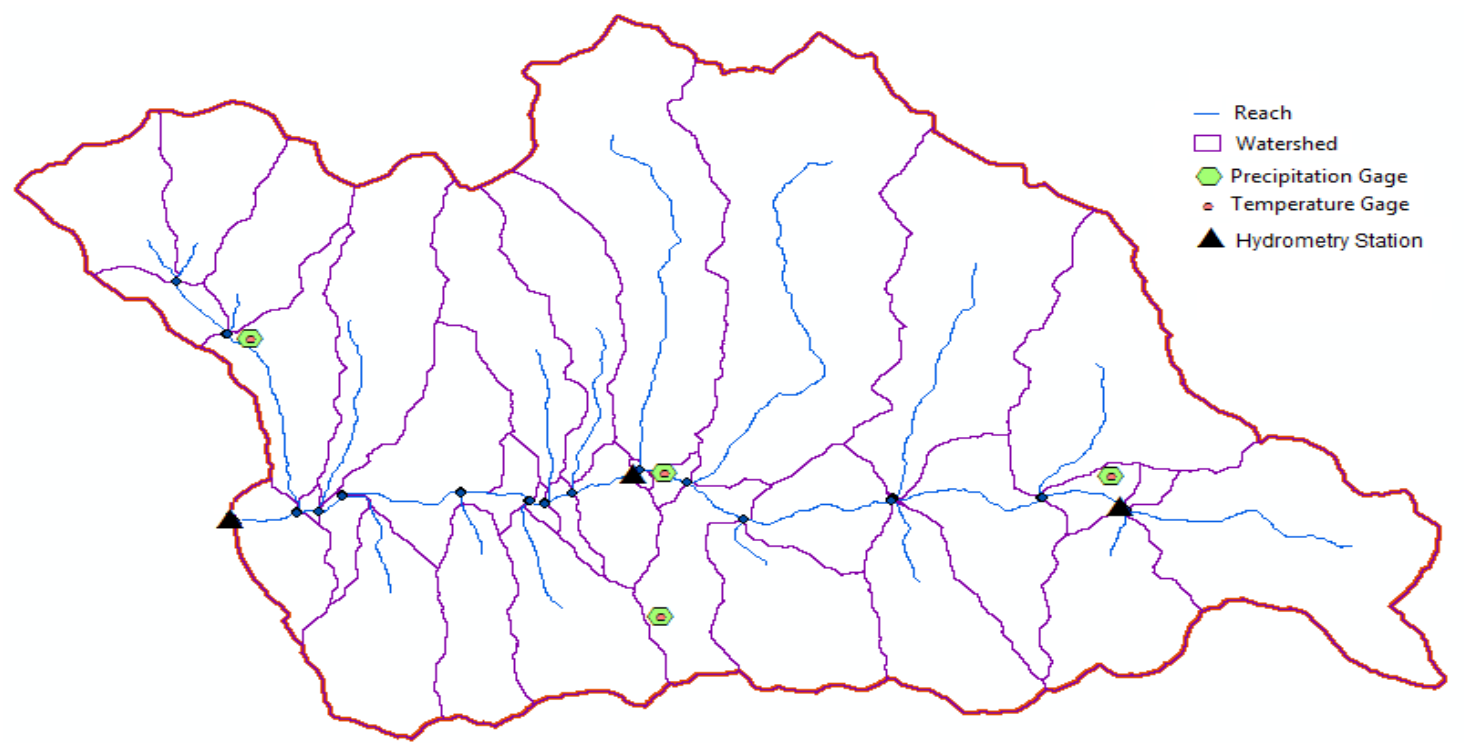

Figure 3. Taleqan watershed, stream flow, weather stations and hydrometric stations

\section{Sensitivity analysis}

The relative importance of input parameters with respect to its output is evaluated typically by using a sensitivity analysis. Parameters represent processes, and sensitivity analysis provides information on the most important processes in the study region. Many parameters are involved in the SWAT model to simulate rainfall-runoff. Thus, reducing the number of parameters by neglecting less effective parameters seems necessary (Zhang et al., 2009; Malago et al., 2017). The sensitivity analysis is performed by means of SWATCUP software, SUFI-2 algorithm. In this algorithm, parameters are changed, and a large number of runs are performed in order to see the impact of each parameter on the objective function. The advantage is that this produces more reliable results. This method uses a multiple regression approach to quantify sensitivity of each parameter (Eq. 3):

$$
g=\alpha+\sum_{i=1}^{n} \beta_{i} b_{i}
$$

Where $g$ is the objective function value, $\alpha$ is the regression constant, $\beta$ is the coefficient of parameters, and $b$ is the relative significance of each parameter (Abbaspour et al., 2018).

After sensitivity analysis, 18 parameters were determined as parameters to which the model is more sensitive. Sensitivity analysis showed that the parameters of the curve 
number $(\mathrm{CN})$ is the most important factor, and soil evaporation compensation factor (ESCO) and soil available water capacity (SOL_AWC) are among the most important factors controlling the flow in the basin, respectively. The parameters' sensitivity ranking is given in Table 2 .

Table 2. Sensitive parameters description and ranking

\begin{tabular}{|c|c|c|c|c|}
\hline $\begin{array}{l}\text { Sensitivity } \\
\text { order }\end{array}$ & Parameter & Description & Domain & $\begin{array}{l}\text { Fitted } \\
\text { value }\end{array}$ \\
\hline 1 & $\mathrm{CN} 2$ & Curve number & mgt & -0.291 \\
\hline 2 & ESCO & Soil evaporation compensation factor & hru & 0.965 \\
\hline 3 & SOL_AWC & Available soil water capacity & sol & 0.379 \\
\hline 4 & GW_DELAY & $\begin{array}{l}\text { Time required for water leaving the bottom of } \\
\text { the root zone to reach the shallow aquifer }\end{array}$ &.$g w$ & 56.213 \\
\hline 5 & SNO50COV & & bsn & 0.578 \\
\hline 6 & ALPHA_BF & $\begin{array}{l}\text { Baseflow alpha factor, lower number means a } \\
\text { slower response }\end{array}$ &.$g w$ & 0.142 \\
\hline 7 & SNOCOVMX & $\begin{array}{c}\text { Minimum snow water content that corresponds } \\
\text { to } 100 \% \text { snow cover }\end{array}$ &.$b s n$ & 446.116 \\
\hline 8 & SMTMP & Snow melt base temperature &.$b s n$ & -6.297 \\
\hline 9 & SNO_SUB & Initial snow water content & sub & 96.040 \\
\hline 10 & SFTMP & Snowfall temperature &.$b s n$ & 2.902 \\
\hline 11 & ALPHA_BNK & Baseflow alpha factor for bank storage & .rte & 0.078 \\
\hline 12 & GWQMN & $\begin{array}{l}\text { Threshold depth of water in the shallow aquifer } \\
\text { required for return flow to occur }\end{array}$ &. $\mathrm{gw}$ & 0.451 \\
\hline 13 & EPCO & Plant uptake compensation factor & hru & 0.387 \\
\hline 14 & SOL_CBN & Organic carbon content (\% soil weight) & .sol & 13.160 \\
\hline 15 & SURLAG & $\begin{array}{l}\text { Surface lag coefficient; controls fraction of } \\
\text { water entering reach in one day }\end{array}$ &.$b s n$ & 16.062 \\
\hline 16 & SOL_BD & Soil bulk density & .sol & 0.879 \\
\hline 17 & GW_REVAP & $\begin{array}{l}\text { Rate of transfer from shallow aquifer to root } \\
\text { zone }\end{array}$ &.$g w$ & 0.317 \\
\hline 18 & SOL_K & Saturated hydraulic conductivity & sol & 0.376 \\
\hline
\end{tabular}

More sensitivity analysis of the three most sensitive parameters and their effects on the normalized surface runoff changes is done. The results are shown in Figure 4. The runoff shows the greatest sensitivity to $\mathrm{CN}$ parameter. $\mathrm{CN}$ is a dimensionless parameter, which is linked to land use and soil type. Hence, by $10 \%$ positive and negative changes, runoff changes become very significant.

The second parameter in terms of sensitivity is ESCO. ESCO value reduction causes more water transfer to the upper layers of the soil, leading to an increase in the surface runoff. The third sensitive parameter is SOL_AWC. By reducing the amount of this parameter, surface runoff increases. As the empty spaces to hold water decrease, the amount of surface runoff increases. 


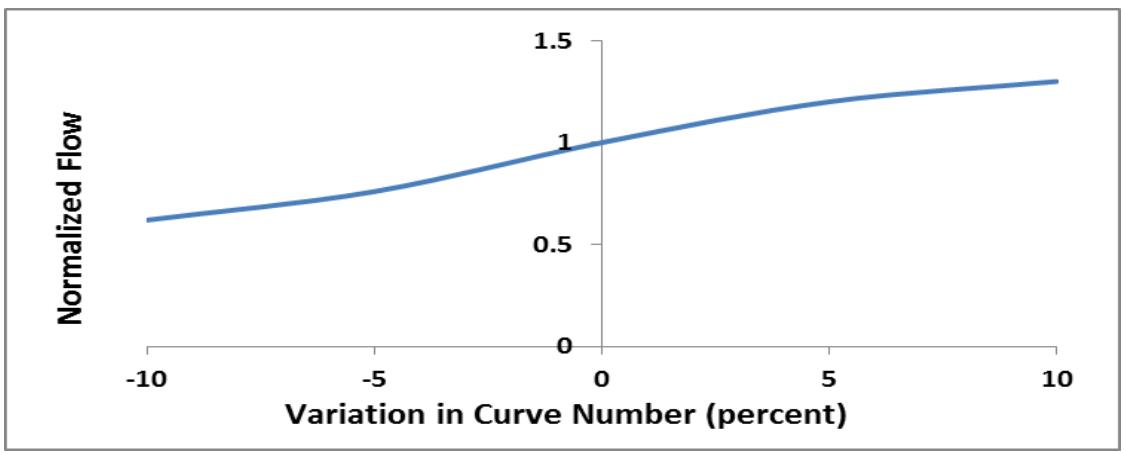

$\mathbf{a}$

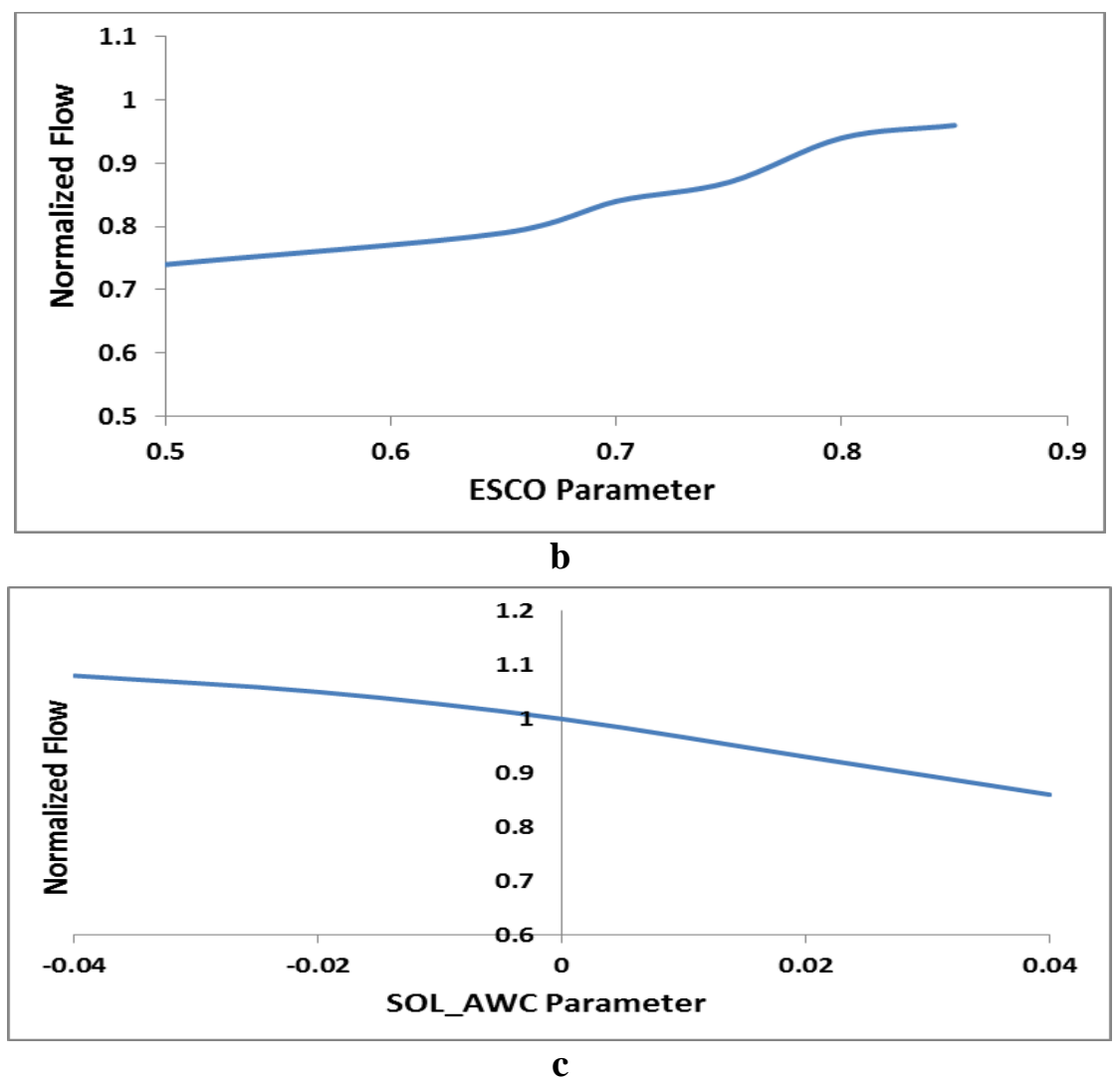

Figure 4. Normalized flow changes due to (a) curve number changes; (b) ESCO parameter changes; (c) SOL_AWC parameter changes

\section{Calibration and validation}

After determining the most sensitive model parameters, the model was calibrated using SUFI-2 algorithm (Abbaspour, 2008) for the years 2000 to 2010, using observed flow data by three hydrometric stations in which characteristics are shown in Table 3. Daily runoff data from these three stations in Iran is collected by the Water Research Institute of Iran. The optimal values of the parameters after calibration are presented in Table 2.

Runoff calibration results in these three stations are shown in the Figure 5. As can be seen, simulated runoff follows observed runoff curve in terms of both the values and the peak values occurrence time. Nash-Sutcliffe coefficient values of statistical indicators (NS) and $\mathrm{R}^{2}$ before and after calibration are shown in Table 4. The values of these 
coefficients after calibration compared to the pre-calibration values are very different. NS coefficients in Gatehdeh, Joestan, and Gelinak are respectively, 0.8, 0.78 and 0.84 and $\mathrm{R}^{2}$ values for these three stations had been estimated $0.86,0.81$ and 0.87 , respectively. The values of these coefficients indicate that the simulation of basin is of good quality. In Figure 6, scatter chart of observed runoff due to simulated runoff values for Gelinak station is shown. It shows high correlation between the observed and simulation values.

Table 3. Watershed hydrometric stations

\begin{tabular}{c|c|c|c}
\hline Station name & X (UTM) & Y (UTM) & Elevation (m) \\
\hline Gatedeh & 506183 & 4003119 & 2320 \\
Joestan & 489962 & 4004430 & 1930 \\
Gelinak & 476567 & 4002534 & 1780 \\
\hline
\end{tabular}

Table 4. Nash-Sutcliffe and $R^{2}$ statistical indexes before and after calibration interval

\begin{tabular}{c|c|c|c|c}
\hline \multirow{2}{*}{ Station name } & \multicolumn{2}{|c|}{ Before calibration } & \multicolumn{2}{c}{ After calibration } \\
\cline { 2 - 5 } & NS & $\mathbf{R}^{\mathbf{2}}$ & NS & $\mathbf{R}^{\mathbf{2}}$ \\
\hline Gatedeh & 0.13 & 0.25 & 0.8 & 0.86 \\
Joestan & 0.27 & 0.46 & 0.78 & 0.81 \\
Gelinak & 0.46 & 0.54 & 0.84 & 0.87 \\
\hline
\end{tabular}

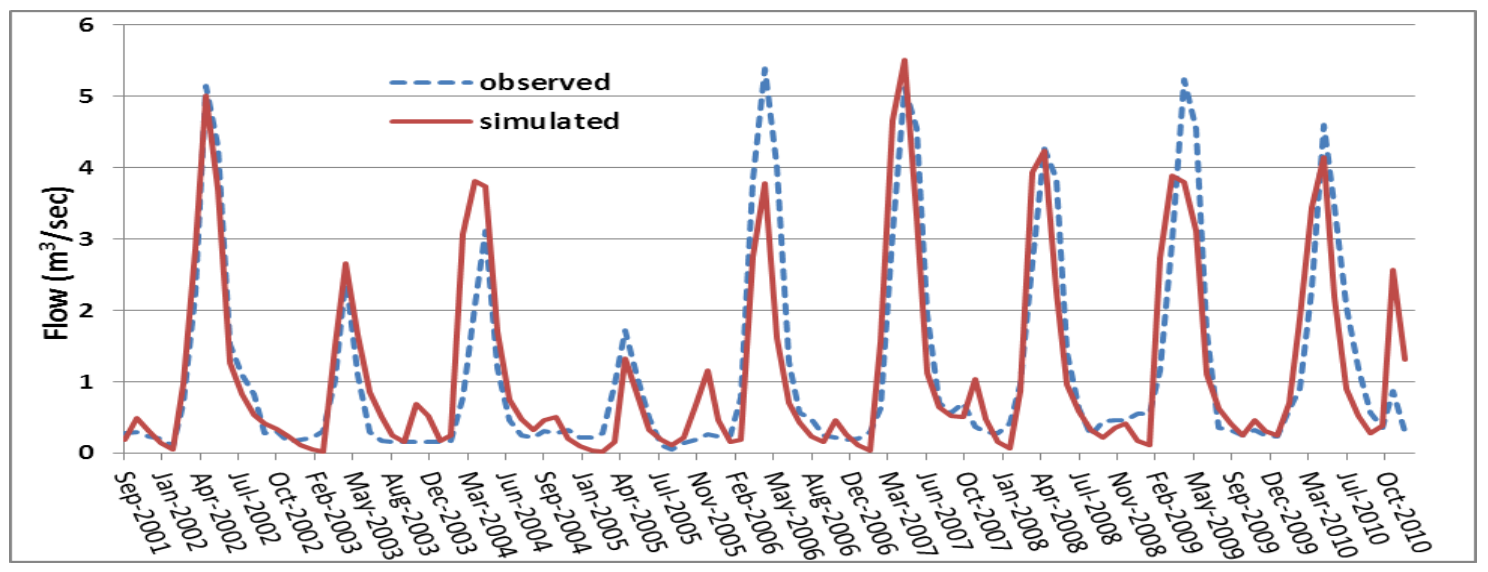

$\mathbf{a}$

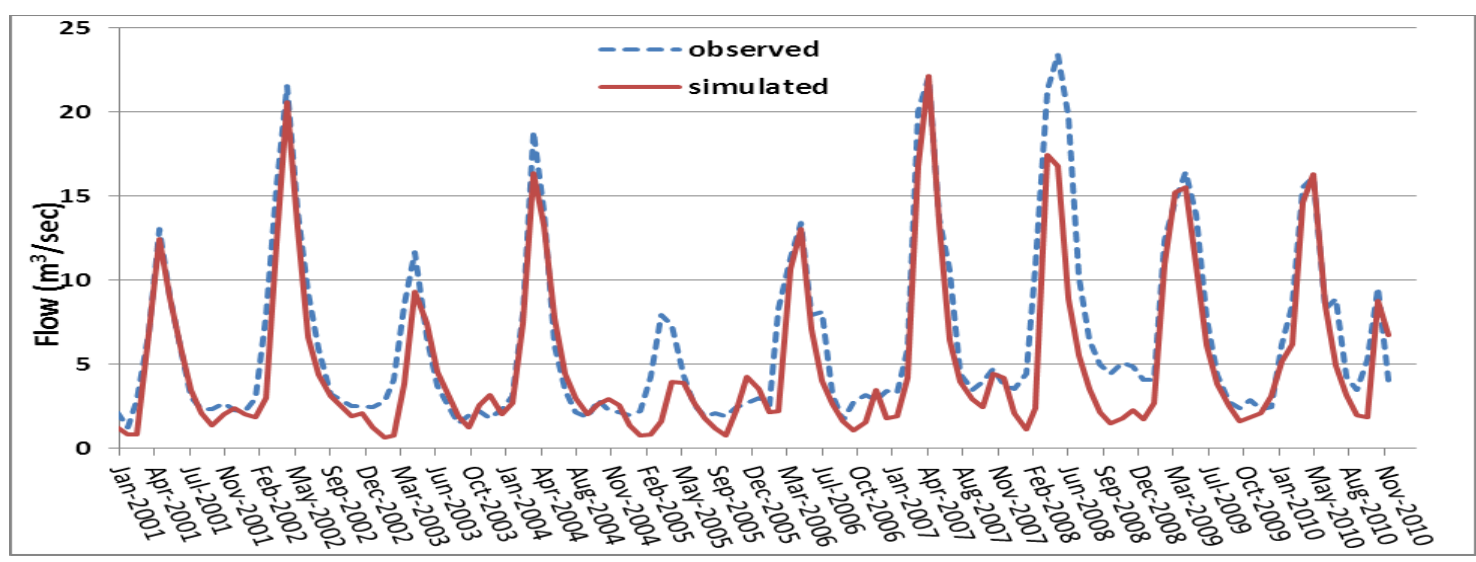

b 


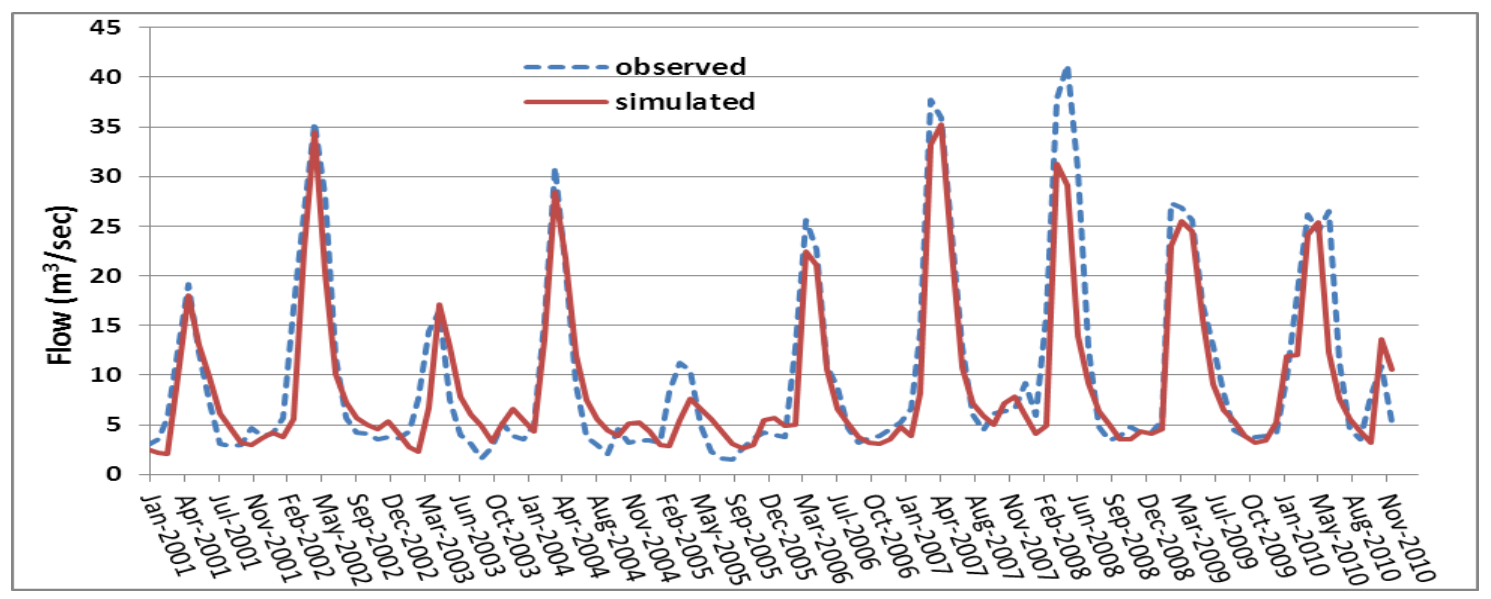

C

Figure 5. Monthly observed and simulated surface runoff in calibration period in (a) Gatehdeh station; (b) Joestan station; (c) Gelinak station

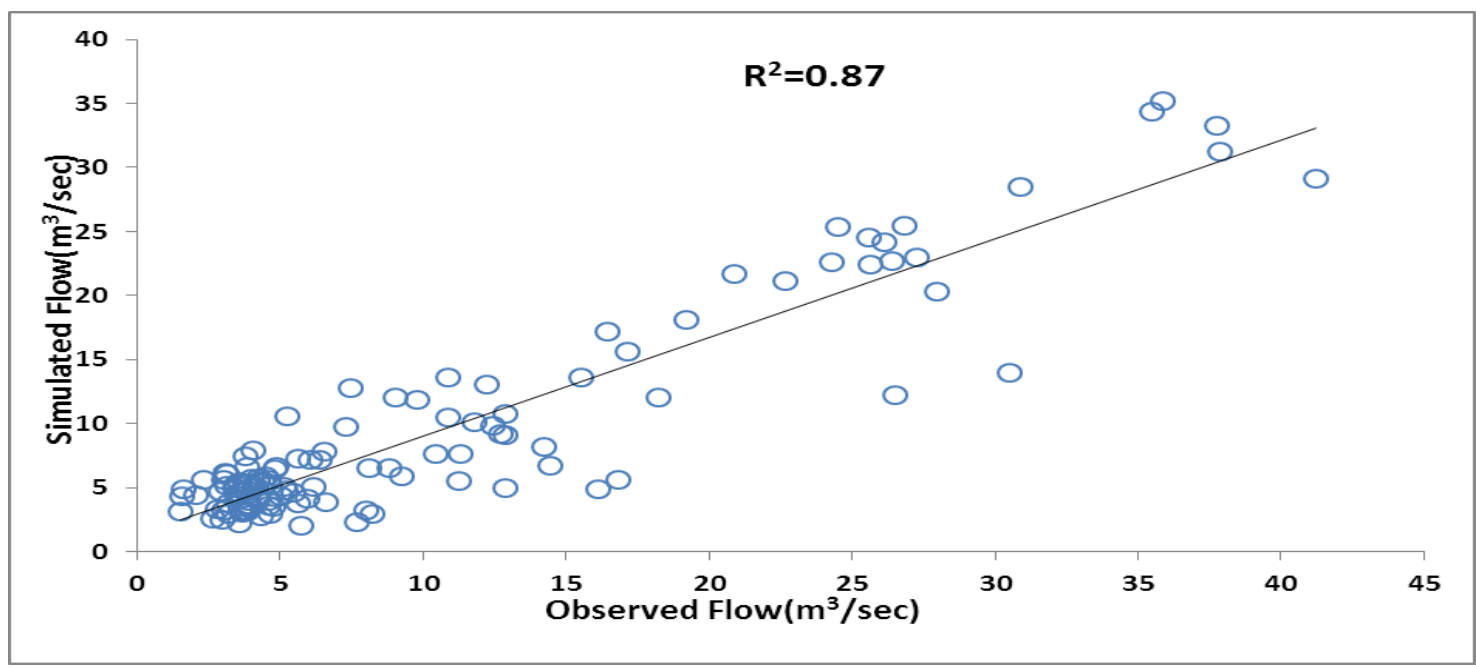

Figure 6. Observed runoff due to simulated runoff values in calibration period for Gelinak station

After model calibration, validation of the model is done using observed data from 2011 to 2014. The results of the model validation in Gelinak station is shown in Figure 7. The values of statistical indicators of Nash-Sutcliffe (NS) and $R^{2}$ coefficients during this period for three stations are shown in Table 5. Regarding the values of statistical indicators, it shows goodness of fit of the model.

Table 5. Nash-Sutcliffe and $R^{2}$ statistical indexes for validation interval

\begin{tabular}{c|c|c}
\hline \multirow{2}{*}{ Station name } & \multicolumn{2}{|c}{ Validation period } \\
\cline { 2 - 3 } & NS & $\mathbf{R}^{\mathbf{2}}$ \\
\hline Gatedeh & 0.76 & 0.85 \\
Joestan & 0.73 & 0.75 \\
Gelinak & 0.79 & 0.84 \\
\hline
\end{tabular}




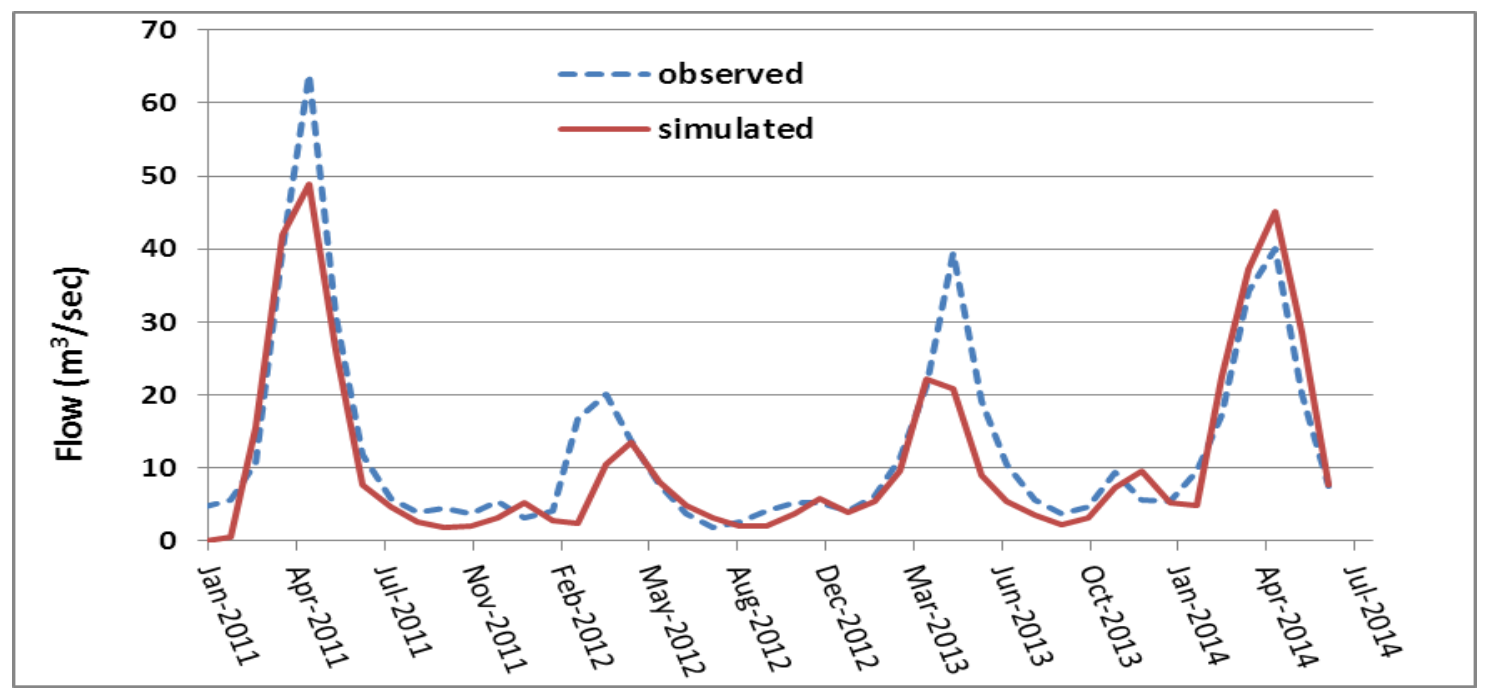

Figure 7. Monthly observed and simulated surface runoff in validation period in Gelinak station

For example, for Gelinak station which is the main basin outlet, the coefficients are 0.79 and 0.84 respectively, which shows the quality of modelling and suitable parameters setting in calibration period.

In Figure 8, a scatter chart of simulated and observed runoff values for the Gelinak station is shown during validation, which indicates acceptable correlation between observed and simulated values

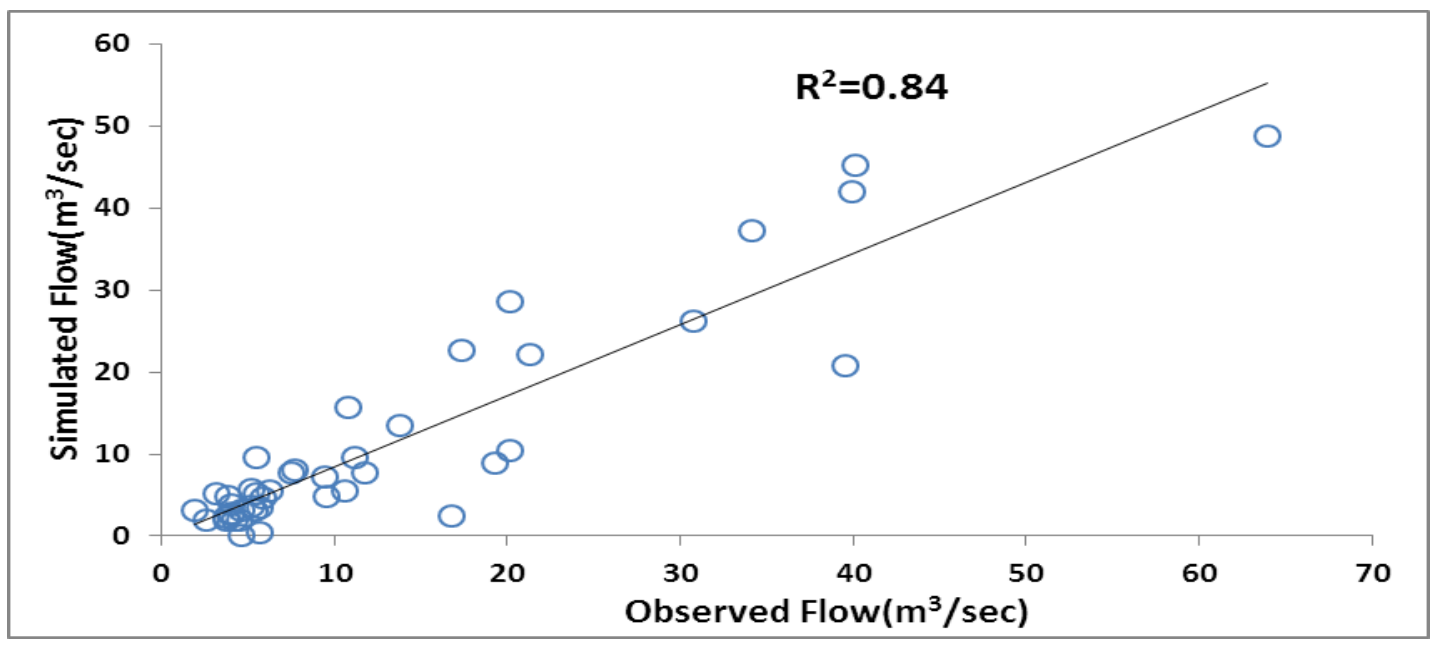

Figure 8. Scatter chart of observed runoff due to simulated runoff values in validation period in Gelinak station

\section{Effects of land use scenarios on surface runoff}

After watershed modelling, the effects of land use changes on surface runoff are investigated. For this purpose, practicable management activities in the watershed are listed in Table 6 by considering existing restrictions. These management options and the 
required conditions are based on the studies performed in Agriculture Office of Alborz Province. The areas in which each management activity can be applied, considering Table 6 conditions, are specified in Figure 9.

Table 6. Management activities and specifications

\begin{tabular}{c|c}
\hline Management activity & Executable areas specifications \\
\hline Afforestation & $\begin{array}{c}\text { Lands with semi-deep or deep soil, low density land cover, max. slope } \\
45 \% \text { and max. elevation } 2600 \mathrm{~m}\end{array}$ \\
\hline Agroforestry & $\begin{array}{c}\text { Agricultural lands with slope of } 15 \% \text { to } 30 \% \text { with semi-deep or deep } \\
\text { soil }\end{array}$ \\
\hline Expansion of agricultural land & $\begin{array}{c}\text { Agricultural lands with max. slope of } 12 \% \text { with deep soil and max. } \\
\text { elevation } 2400 \mathrm{~m}\end{array}$ \\
\hline Agriculture on terrace & Agricultural lands with slope of $12 \%$ to $15 \%$ with deep soil \\
\hline
\end{tabular}

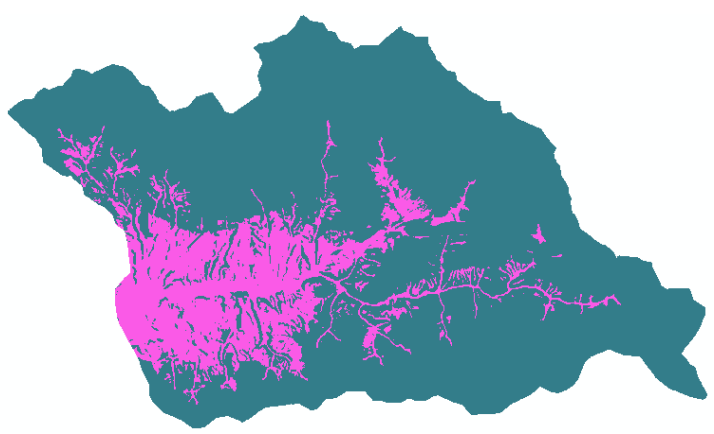

a

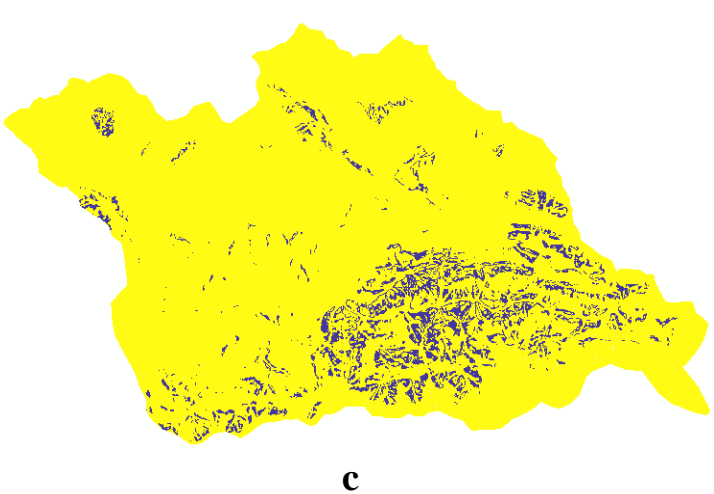

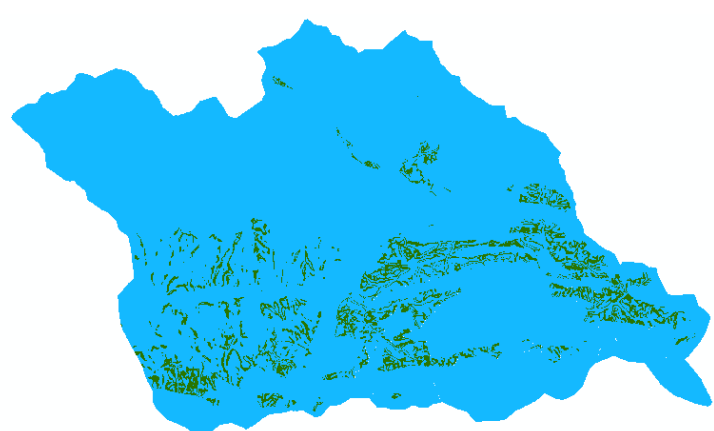

b

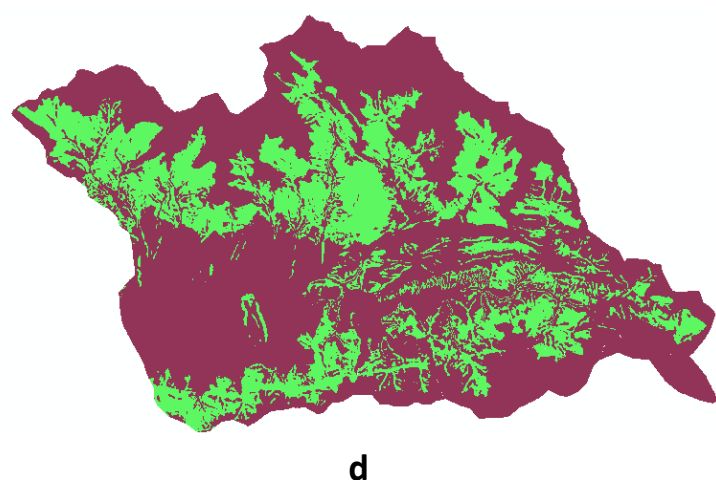

d

Figure 9. Regions in which each management activity can be applied (a) agricultural land; (b) agriculture on terrace lands; (c) agroforestry lands; (d) forest lands

So, combinations of $2^{\mathrm{n}}$ possible management activities are obtained. Where $\mathrm{n}$ is the number of distinct management activities. These management scenarios are shown in Table 7, where scenario sn1 represents the current land use. Table 8 expresses each scenario land use details in percent. Figure 10 shows each scenario information, including different types of land uses and corresponding areas. 
Table 7. Possible management scenarios

\begin{tabular}{c|c|c|c|c|c|c|c|c|c|c|c|c|c|c|c|c}
\hline $\begin{array}{c}\text { Management } \\
\text { activity }\end{array}$ & sn1 & sn2 & sn3 & sn4 & sn5 & sn6 & sn7 & sn8 & sn9 & sn10 & sn11 & sn12 & sn13 & sn14 & sn15 & sn16 \\
\hline $\begin{array}{c}\text { Agriculture on } \\
\text { terrace }\end{array}$ & 0 & 1 & 0 & 0 & 0 & 1 & 0 & 0 & 1 & 1 & 0 & 1 & 0 & 1 & 1 & 1 \\
\hline Afforestation & 0 & 0 & 1 & 0 & 0 & 1 & 1 & 0 & 0 & 0 & 1 & 1 & 1 & 1 & 0 & 1 \\
\hline $\begin{array}{c}\text { Expansion of } \\
\text { agricultural land }\end{array}$ & 0 & 0 & 0 & 1 & 0 & 0 & 1 & 1 & 1 & 0 & 0 & 1 & 1 & 0 & 1 & 1 \\
\hline Agroforestry & 0 & 0 & 0 & 0 & 1 & 0 & 0 & 1 & 0 & 1 & 1 & 0 & 1 & 1 & 1 & 1 \\
\hline
\end{tabular}

' 1 ' represents for application of the activity

' 0 ' represents for not applying the activity

Table 8. Each scenario land use details (in percent)

\begin{tabular}{|c|c|c|c|c|c|c|c|c|c|c|c|c|c|c|c|c|}
\hline Land use & sn1 & \begin{tabular}{|l|l|} 
sn2 \\
\end{tabular} & sn3 & sn4 & sn5 & sn6 & sn7 & sn8 & sn9 & sn10 & sn11 & sn12 & sn13 & sn14 & sn15 & sn16 \\
\hline $\begin{array}{c}\text { Agriculture } \\
\text { on terrace }\end{array}$ & 0 & 6.3 & 0 & 0 & 0 & 6.3 & 0 & 0 & 6.3 & 6.3 & 0 & 6.3 & 0 & 6.3 & 6.3 & 6.3 \\
\hline Forest & 0 & 0 & 34.2 & 0 & 0 & 34.2 & 34.2 & 0 & 0 & 0 & 32.1 & 34.2 & 32.1 & 32.1 & 0 & 32.1 \\
\hline $\begin{array}{c}\text { Agricultural } \\
\text { land }\end{array}$ & 6.5 & 6.5 & 6.5 & 23.4 & 6.5 & 6.5 & 23.4 & 23.4 & 23.4 & 6.5 & 6.5 & 23.4 & 23.4 & 6.5 & 23.4 & 23.4 \\
\hline $\begin{array}{c}\text { Agroforestry } \\
\text { land }\end{array}$ & 0 & 0 & 0 & 0 & 8.7 & 0 & 0 & 8.7 & 0 & 8.7 & 8.7 & 0 & 8.7 & 8.7 & 8.7 & 8.7 \\
\hline Pasture & 89.4 & 83.1 & 55.2 & 72.5 & 80.7 & 48.9 & 38.3 & 63.8 & 66.2 & 74.4 & 48.6 & 32 & 31.7 & 42.3 & 57.5 & 25.4 \\
\hline $\begin{array}{l}\text { Rock out- } \\
\text { crop }\end{array}$ & 4.1 & 4.1 & 4.1 & 4.1 & 4.1 & 4.1 & 4.1 & 4.1 & 4.1 & 4.1 & 4.1 & 4.1 & 4.1 & 4.1 & 4.1 & 4.1 \\
\hline
\end{tabular}

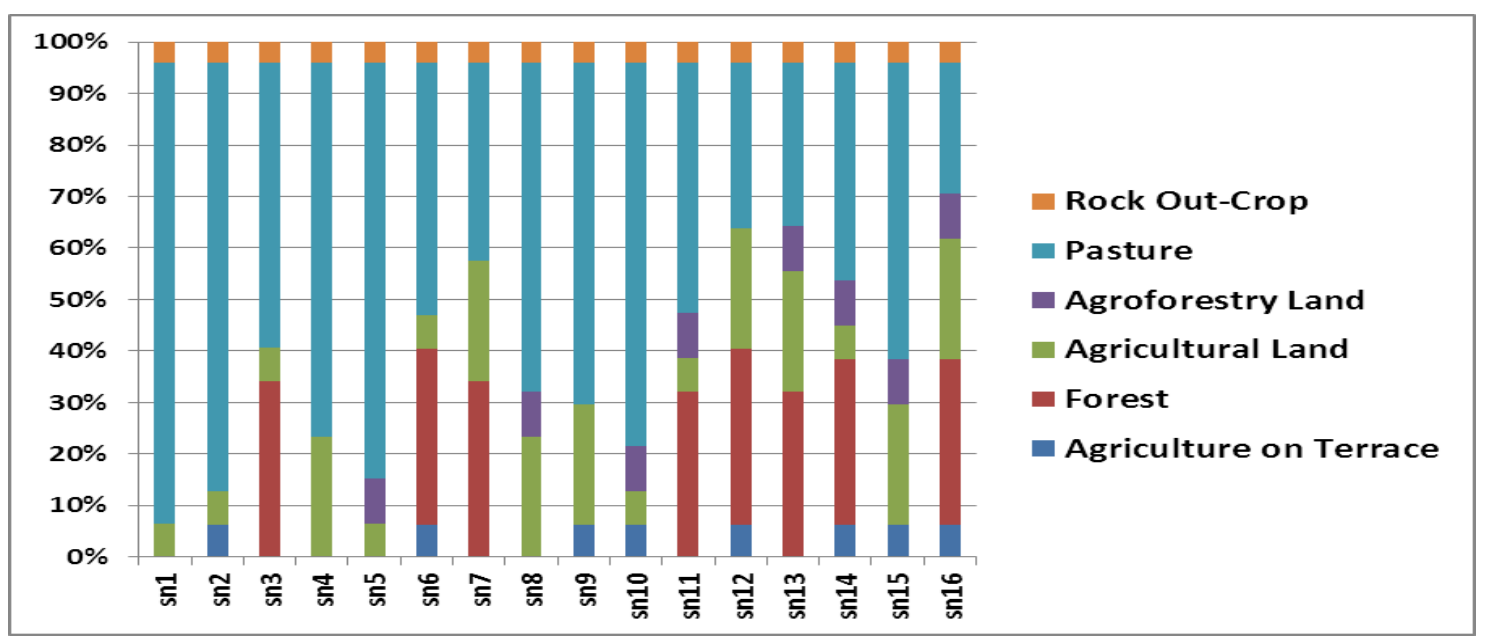

Figure 10. Types of land uses and corresponding areas for each scenario (in percent)

To estimate surface runoff from changes in land use scenarios, the SWAT model was run in the range of calibrated parameters. Table 9 shows changes in average seasonal and annual surface runoff (in percent) for each management scenario. According to the results, applying management scenarios to the watershed leads to changes in runoff compared to current condition. It can be seen that applying scenario sn2 (agriculture on 
terrace) reduces average annual surface runoff less than 2\%. However, sn3 (afforestation) decreases average annual runoff about 5\%. Expansion of agricultural lands and agroforestry activities change runoff by $3.15 \%$ and $3.62 \%$, respectively. Among individual scenarios, sn3 is the most effective management activity for runoff control due to good potential of this watershed for afforestation.

Each of scenarios sn6 to sn11 is obtained by combining two management activities. Application of sn6 (combination of agriculture on terrace and afforestation) reduces average runoff by $8 \%$. Scenario sn7 (combination of expansion of agricultural land and afforestation) affects average annual runoff about 10\%. Scenarios sn8 (combination of expansion of agricultural land and agroforestry), sn9 (combination of expansion of agricultural land and agriculture on terrace) and sn10(combination of agroforestry and agriculture on terrace) reduce surface runoff less than $7 \%$. However, by applying sn11 (combination of agroforestry and afforestation activities), the average runoff is decreased more than $12 \%$ compared to current land use condition. Considering combinations of two management options (scenario sn6 to scenario sn11), it can be observed that the most effective scenario for runoff management is sn11.

Considering combinations of three management options (scenario sn12 to scenario sn15), sn13 (combination of afforestation, expansion of agricultural land and agroforestry activities) have the greatest impact on reducing runoff. By applying scenario sn13, average annual surface runoff is reduced by $19 \%$. The second effective scenario in this category is sn 14 , which reduces runoff more than $16 \%$. This scenario is the combination of afforestation, agriculture on terrace and agroforestry activities. Sn12 (combination of afforestation, agriculture on terrace and expansion of agricultural land activities) and sn15 (combination of expansion of agricultural land, agriculture on terrace and agroforestry activities) affects watershed average runoff by $14.43 \%$ and $13.48 \%$, respectively.

Table 9. Average seasonal and annual runoff changes (in percent) for each management scenario

\begin{tabular}{c|c|c|c|c|c|c|c|c|c|c|c|c|c|c|c|c}
\hline $\begin{array}{c}\text { Seasonal/ } \\
\text { annual } \\
\text { interval }\end{array}$ & $\mathbf{s n 1}$ & $\mathbf{s n 2}$ & $\mathbf{s n 3}$ & $\mathbf{s n 4}$ & $\mathbf{s n 5}$ & $\mathbf{s n 6}$ & $\mathbf{s n 7}$ & $\mathbf{s n 8}$ & $\mathbf{s n 9}$ & $\mathbf{s n 1 0}$ & $\mathbf{s n 1 1}$ & $\mathbf{s n 1 2}$ & $\mathbf{s n 1 3}$ & $\mathbf{s n 1 4}$ & $\mathbf{s n 1 5}$ & sn16 \\
\hline Spring & 0 & -1.64 & -4.71 & -3.14 & -3.32 & -7.44 & -8.66 & -6.53 & -5.81 & -6.61 & -12.02 & -14.06 & -18.29 & -16.18 & -13.12 & -21.88 \\
\hline Summer & 0 & -1.86 & -5.10 & -3.40 & -4.17 & -9.83 & -11.34 & -7.84 & -6.72 & -7.11 & -13.33 & -15.22 & -19.85 & -17.47 & -14.24 & -23.52 \\
\hline Autumn & 0 & -1.78 & -4.92 & -3.28 & -3.87 & -8.12 & -10.08 & -7.21 & -6.36 & -6.89 & -12.55 & -14.71 & -18.94 & -16.88 & -13.75 & -22.69 \\
\hline Winter & 0 & -1.70 & -4.17 & -2.78 & -3.12 & -6.93 & -9.58 & -6.21 & -5.44 & -6.73 & -11.68 & -13.73 & -18.68 & -15.55 & -12.82 & -21.16 \\
\hline Annual & 0 & -1.75 & -4.68 & -3.15 & -3.62 & -8.08 & -9.92 & -6.95 & -6.08 & -6.84 & -12.40 & -14.43 & -18.94 & -16.52 & -13.48 & -22.31 \\
\hline
\end{tabular}

The last management scenario is the combination of all land use options. Scenario sn16 land use map is shown in Figure 11. It can be observed that by applying this scenario, surface runoff decreases more than $22 \%$ compared to the current condition. This scenario makes the most significant effect on the average runoff compared to the other management scenarios. Moreover, by considering average seasonal runoff changes, it can be seen that the most decrease in surface runoff occurs in summer in each scenario. On the other hand, the least changes occur in winter.

Figure 12 shows average annual surface runoff resulted from each scenario application. Terrace agriculture (sn2) does not affect surface runoff considerably. However, from scenario sn6 (combination of management options) onwards, decrease 
in surface runoff is noticeable. It can be seen that average annual runoff is $126 \mathrm{~m}^{3} / \mathrm{s}$ considering current land use. However, it is reduced to $108 \mathrm{~m}^{3} / \mathrm{s}$ by applying sn11 (combination of agroforestry and afforestation activities) and to $100 \mathrm{~m}^{3} / \mathrm{s}$ by applying sn13 (combination of afforestation, expansion of agricultural land and agroforestry activities). The main change occurs when sn16 land use scenario is applied to the model and the average annual runoff is reduced to about $95 \mathrm{~m}^{3} / \mathrm{s}$.

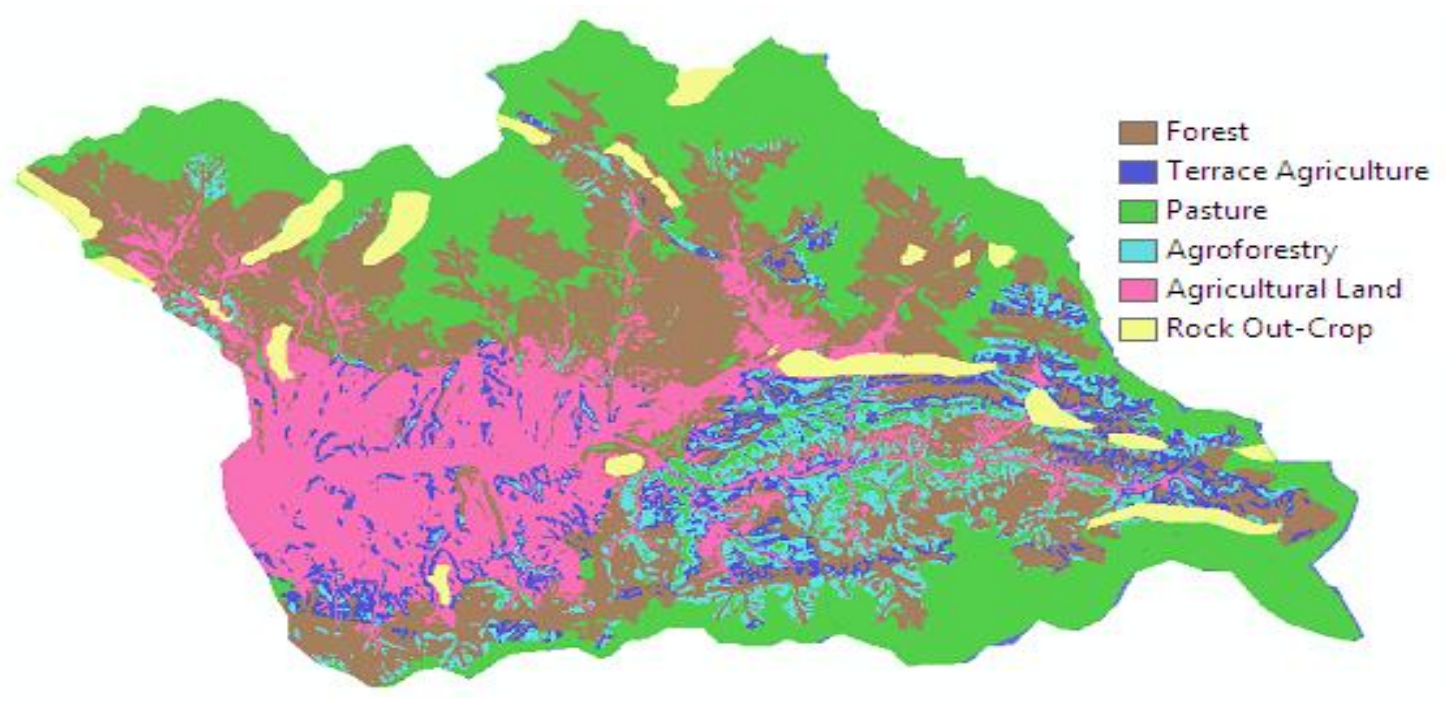

Figure 11. Scenario sn16 land use map

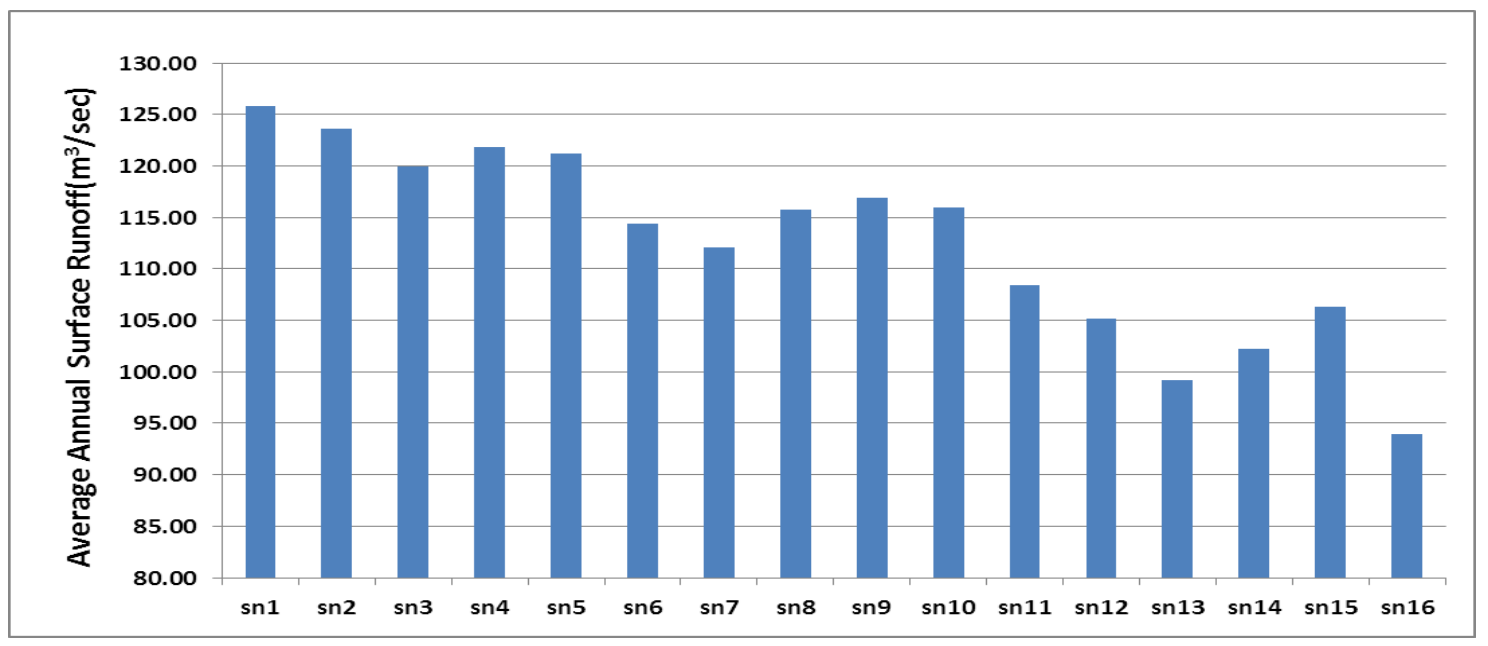

Figure 12. Average annual surface runoff resulted from each scenario application

In recent years, some researches were performed to study the impacts of land use changes on the study area flow. In a study by Kazemi and Bayat (2017), by using topographical maps and aerial photographs, land use maps of 1971, 1988 and 2003 were prepared. Then land use change was calculated. Then relationship between low flow indices and land use in the period of study were investigated. The results showed that the low flow indices have experienced an upward trend. Increasing rangeland coverage during these years was in accordance with the increasing of indices in the period 
studied. It was concluded that land use changes due to human intervention has a direct impact on the trend of low flow indices.

Hosseini et al. (2012) studied the effects of land use changes on water balance of the Taleqan catchment before and after the dam construction by using SWAT. The results indicated progressive increase in surface runoff and decline in interflow and groundwater flow. Therefore, one of the main challenges facing development planners is the control of the accelerated degradation of the natural resources.

In these researches, the impacts of land use changes on the watershed in the past time periods were studied. However, in the current work all possible land use scenarios were introduced to the model to study the corresponding future land use scenarios effects on the watershed. Since, decision makers can make the best decisions due to environmental consequences by assessing the results of each land use scenario simulation before implementation.

\section{Conclusions}

In this study, Taleqan watershed modelling was done using the Soil and Water Assessment Tool (SWAT). In order to do this, different kinds of information such as digital elevation model (DEM), soil data, temperature and precipitation data, and soil and land use maps in standard formats were provided as inputs for the model.

The relative importance of input parameters with respect to its output was evaluated using sensitivity analysis. Sensitivity analysis showed that the curve number (CN) parameter is the most important factor and Soil Evaporation Compensation Factor (ESCO) and soil available water capacity (SOL_AWC) are among the most important factors affecting the flow in the basin, respectively.

Calibration was performed by SUFI-2 algorithm, using river flow observation of three hydrometric stations within the basin.

It was observed that simulated values follow observed values of both the amplitude and the time of couriers. Nash-Sutcliffe coefficients in Gatehdeh, Joestan, and Gelinak stations are respectively $0.8,0.78$, and 0.84 and the $\mathrm{R}^{2}$ values for these three stations were $0.86,0.81$, and 0.87 , respectively. It was shown that the values of these statistical indicators after calibration compared to the pre-calibration values are very different. The statistical indicators values indicate that the basin modelling and simulations were performed with good quality.

After model calibration, it is necessary to ensure the quality of the modelling by means of validation process. Validation results in hydrometric stations show watershed modelling quality and suitable parameter settings in calibration period. NS and $\mathrm{R}^{2}$ coefficients values were convenient. For example, in Gelinak station, which is the main outlet of the watershed, these indexes are 0.79 and 0.84 . Moreover, scatter charts of observed and simulated surface runoff showed good correlation between these values in both calibration and validation intervals.

The effects of land use changes on the basin surface runoff were studied. It was seen that by applying scenario sn16, the most reduction in surface runoff was obtained compared to the other scenarios. Application of this scenario leads to $22.31 \%$ reduction in runoff compared to current condition. Moreover, in all scenarios, effects of management activities in the summer are the most. This can be due to the evolution of land cover and canopy, which in addition to significant evapotranspiration, makes runoff to decrease. According to results, management options combinations reduce 
surface runoff considerably compared to individual activities. Afforestation is the most effective activity among single options. Considering combinations of two management options, the most effective scenario is sn11 (a combination of afforestation and agroforestry activities), which changes surface runoff about $12.4 \%$ compared to current land use condition. On the other hand, sn9 has the least impact on runoff (about $6 \%$ reduction). However, in this condition, runoff decreases more than scenario sn5 (the most effective singular activity).

Considering combinations of three management options, sn13 (a combination of afforestation, expansion of agricultural land, and agroforestry activities) have the greatest impact on reducing runoff. By applying scenario sn13, surface runoff is reduced by $18.94 \%$ compared to the current condition, which is considered a significant change. Moreover, scenario sn14 reduces surface runoff by $16.52 \%$. This scenario applies a combination of afforestation, agriculture on terrace, and agroforestry activities.

\section{REFERENCES}

[1] Abbaspour, K. C. (2008): SWAT-CUP2: SWAT Calibration and Uncertainty ProgramsA User Manual. - Department of Systems Analysis, Swiss Federal Institute of Aquatic Science and Technology, Dübendorf.

[2] Abbaspour, K. C., Vaghefi, S. A., Srinivasan, R. (2018): A guideline for successful calibration and uncertainty analysis for soil and water assessment: a review of papers from the 2016 International SWAT Conference. - Water Journal 10(1): 1-18.

[3] Afzal, M., Gagnon, A. S., Mansell, M. G. (2015): The impact of projected changes in climate variability on the reliability of surface water supply in Scotland. - Water Science and Technology: Water Supply 15(4): 736-745.

[4] Arnold, J. G., Srinivasan, R, Muttiah, R. S., Williams, J. R. (1998): Large-area hydrologic modeling and assessment: Part I. Model development. - Journal of the American Water Resources Association 34(1): 73-89.

[5] Azzellino, A., Çevirgen, S., Giupponi, C., Parati, P., Ragusa, F., Salvetti, R. (2015): Flow and sediment yield simulations for Bukit Merah Reservoir catchment, Malaysia: a case study. - Water Science and Technology 72(12): 2103-2111.

[6] Bonansea, M., Ledesma, C., Rodriguez, M. C. (2015): Assessing the impact of land use and land cover on water quality in the watershed of a reservoir. - Applied Ecology and Environmental Research 14(2): 447-456.

[7] Cho, H., Olivera, F. (2009): Effect of the spatial variability of land use, soil type, and precipitation on streamflows in small watersheds. - Journal of the American Water Resources Association 45(3): 673-686.

[8] Ghoraba, S. M. (2015): Hydrological modeling of the Simly Dam watershed (Pakistan) using GIS and SWAT model. - Alexandria Engineering Journal 54(3): 583-594.

[9] Gosain, A. K., Rao, S., Basuray, D. (2006): Climate change impact assessment on hydrology of Indian river basins. - Current Science 90(3): 346-353.

[10] Hosseini, M., Ghafouri, A. M., Amin, M. S. M., Tabatabaei, M. R., Goodarzi, M., Abde Kolahchi, A. (2012): Effects of land use changes on water balance in Taleghan Catchment, Iran. - Journal of Agricultural Science and Technology 14: 1159-1172.

[11] Jung, C. G., Kim, S. J. (2017): Evaluation of land use change and groundwater use impact on stream drying phenomena using a grid-based continuous hydrologic model. - Paddy and Water Environment 15(1): 112-122.

[12] Kazemi, R., Bayat, R. (2017): Investigation of the effects of land use change on low flow indices (Case study: Taleqan catchment). - Journal of Water and Soil Conservation 24(1): 287-294. 
[13] Kim, T. J. (2015): Generation of daily naturalized flow at ungaged control points. Journal of Water Supply Research and Technology: AQUA 64(3): 354-364.

[14] Krause, P., Boyle, D. P., Base, F. (2005): Comparison of different efficiency criteria for hydrological model assessment. - Advances in Geosciences 5: 89-97.

[15] Li, Q., Qi, J., Xing, Z., Jiang, Y., Danielescu, S., Zhu, H., Wei, X., Meng, F. R. (2014): An approach for assessing impact of landuse and biophysical conditions across landscape on recharge rate and nitrogen loading of groundwater. - Agriculture, Ecosystems and Environment Journal 196: 114-124.

[16] Malago, A., Bouraoui, F., Vigiak, O., Grizzetti, B., Pastori, M. (2017): Modelling water and nutrient fluxes in the Danube River Basin with SWAT. - Science of The Total Environment 603-604: 196-218.

[17] Nash, J. E., Sutcliffe, J. V. (1970): River flow forecasting through conceptual models, Part I - A discussion of principles. - Journal of Hydrology 10: 282-290.

[18] Neitsch, S. L., Arnold, J. G., Kiniry, J. R., Williams, J. R., King, K. W. (2011): Soil and Water Assessment Tool Theoretical Documentation-Version 2009. - Soil and Water Research Laboratory, Agricultural Research Service, Blackland Research Center-Texas AgriLife Research, Texas.

[19] Ouyang, W., Song, K., Wang, X., Hao, F. (2013): Non-point source pollution dynamics under long-term agricultural development and relationship with landscape dynamics. Ecological Indicators Journal 45: 579-589.

[20] Pereira, D. R., Almeida, A. Q., Martinez, M. A., Rosa, D. R. Q. (2014): Impacts of deforestation on water balance components of a watershed on the Brazilian East Coast. Revista Brasileira de Ciência do Solo Journal 38(4): 1350-1358.

[21] Rahman, K., Maringantic, H., Beniston, M., Widmer, F., Abbaspour, K., Lehmann, A. (2013): Streamflow modeling in a highly managed mountainous glacier watershed using SWAT: The Upper Rhone River watershed case in Switzerland. - Water Resources Management 27(2): 323-339.

[22] Romagnoli, M., Portapila, M., Rigalli, A., Maydana, G., Burgues, M., García, C. M. (2017): Assessment of the SWAT model to simulate a watershed with limited available data in the Pampas region. - Argentina. Science of The Total Environment 596-597: 437450.

[23] Santhi, C., Arnold, J. G., Williams, J. R., Dugas, W. A., Srinivasan, R., Hauck, L. M. (2001): Validation of the SWAT model on a large river basin with point and nonpoint sources. - Journal of American Water Resources Association 37(5): 1169-1188.

[24] Santos, R. M., Sanches Fernandes, L. F., Moura, J. P., Pereira, M. G., Pacheco, F. A. L. (2014): The impact of climate change, human interference, scale and modeling uncertainties on the estimation of aquifer properties and river flow components. - Journal of Hydrology 519: 1297-1314.

[25] Setegn, S. G., Srinivasan, R., Dargahi, B. (2008): Hydrological modeling in the Lake Tana basin, Ethiopia using SWAT model. - The Open Hydrology Journal 2(1): 49-62.

[26] Shahoei, S. V., Porhemmat, J., Sedghi, H., Hosseini, M., Saremi, A. (2017): Daily runoff simulation using remote sensing through SRM model and comparison to SWAT model. Applied Ecology and Environmental Research 15(3): 1843-1862.

[27] Vilaysane, B., Takara, K., Luo, P., Akkharath, I., Duana, W. (2015): Hydrological stream flow modeling for calibration and uncertainty analysis using SWAT model in the Xedone river basin, Lao PDR. - Procedia Environmental Sciences 28: 380-390.

[28] Zhang, X., Srinivasan, R., Bosch, D. (2009): Calibration and uncertainty analysis of the SWAT model using Genetic Algorithms and Bayesian Model Averaging. - Journal of Hydrology 374(3-4): 307-317. 


\section{APPENDIX}

Appendix 1. The study area summarised data used for modelling

\begin{tabular}{|c|c|c|}
\hline Parameter & Description & Value \\
\hline TMPMX1 & Average daily maximum air temperature for January $\left({ }^{\circ} \mathrm{C}\right)$ & 2.58 \\
\hline TMPMX2 & Average daily maximum air temperature for February $\left({ }^{\circ} \mathrm{C}\right)$ & 4.45 \\
\hline TMPMX3 & Average daily maximum air temperature for March $\left({ }^{\circ} \mathrm{C}\right)$ & 11.12 \\
\hline TMPMX4 & Average daily maximum air temperature for April $\left({ }^{\circ} \mathrm{C}\right)$ & 17.94 \\
\hline TMPMX5 & Average daily maximum air temperature for May $\left({ }^{\circ} \mathrm{C}\right)$ & 24.43 \\
\hline TMPMX6 & Average daily maximum air temperature for June $\left({ }^{\circ} \mathrm{C}\right)$ & 30.52 \\
\hline TMPMX7 & Average daily maximum air temperature for July $\left({ }^{\circ} \mathrm{C}\right)$ & 33.66 \\
\hline TMPMX8 & Average daily maximum air temperature for August $\left({ }^{\circ} \mathrm{C}\right)$ & 32.29 \\
\hline TMPMX9 & Average daily maximum air temperature for September $\left({ }^{\circ} \mathrm{C}\right)$ & 27.37 \\
\hline TMPMX10 & Average daily maximum air temperature for October $\left({ }^{\circ} \mathrm{C}\right)$ & 20.22 \\
\hline TMPMX11 & Average daily maximum air temperature for November $\left({ }^{\circ} \mathrm{C}\right)$ & 10.51 \\
\hline TMPMX12 & Average daily maximum air temperature for December $\left({ }^{\circ} \mathrm{C}\right)$ & 4.75 \\
\hline TMPMN1 & Average daily minimum air temperature for January $\left({ }^{\circ} \mathrm{C}\right)$ & -9.20 \\
\hline TMPMN2 & Average daily minimum air temperature for February $\left({ }^{\circ} \mathrm{C}\right)$ & -6.52 \\
\hline TMPMN3 & Average daily minimum air temperature for $\operatorname{March}\left({ }^{\circ} \mathrm{C}\right)$ & -1.62 \\
\hline TMPMN4 & Average daily minimum air temperature for April $\left({ }^{\circ} \mathrm{C}\right)$ & 3.06 \\
\hline TMPMN5 & Average daily minimum air temperature for May $\left({ }^{\circ} \mathrm{C}\right)$ & 7.32 \\
\hline TMPMN6 & Average daily minimum air temperature for June $\left({ }^{\circ} \mathrm{C}\right)$ & 12.00 \\
\hline TMPMN7 & Average daily minimum air temperature for July $\left({ }^{\circ} \mathrm{C}\right)$ & 15.47 \\
\hline TMPMN8 & Average daily minimum air temperature for August $\left({ }^{\circ} \mathrm{C}\right)$ & 14.59 \\
\hline TMPMN9 & Average daily minimum air temperature for September $\left({ }^{\circ} \mathrm{C}\right)$ & 10.74 \\
\hline TMPMN10 & Average daily minimum air temperature for October $\left({ }^{\circ} \mathrm{C}\right)$ & 5.41 \\
\hline TMPMN11 & Average daily minimum air temperature for November $\left({ }^{\circ} \mathrm{C}\right)$ & -0.07 \\
\hline TMPMN12 & Average daily minimum air temperature for December $\left({ }^{\circ} \mathrm{C}\right)$ & -4.68 \\
\hline TMPSTDMX1 & Average total monthly precipitation in January $\left({ }^{\circ} \mathrm{C}\right)$ & 3.54 \\
\hline TMPSTDMX2 & Average total monthly precipitation in February $\left({ }^{\circ} \mathrm{C}\right)$ & 3.81 \\
\hline TMPSTDMX3 & Average total monthly precipitation in $\operatorname{March}\left({ }^{\circ} \mathrm{C}\right)$ & 4.99 \\
\hline TMPSTDMX4 & Average total monthly precipitation in April $\left({ }^{\circ} \mathrm{C}\right)$ & 4.58 \\
\hline TMPSTDMX5 & Average total monthly precipitation in May $\left({ }^{\circ} \mathrm{C}\right)$ & 3.59 \\
\hline TMPSTDMX6 & Average total monthly precipitation in June $\left({ }^{\circ} \mathrm{C}\right)$ & 3.31 \\
\hline TMPSTDMX7 & Average total monthly precipitation in July $\left({ }^{\circ} \mathrm{C}\right)$ & 2.45 \\
\hline TMPSTDMX8 & Average total monthly precipitation in August $\left({ }^{\circ} \mathrm{C}\right)$ & 2.51 \\
\hline TMPSTDMX9 & Average total monthly precipitation in September $\left({ }^{\circ} \mathrm{C}\right)$ & 3.10 \\
\hline TMPSTDMX10 & Average total monthly precipitation in October $\left({ }^{\circ} \mathrm{C}\right)$ & 3.77 \\
\hline TMPSTDMX11 & Average total monthly precipitation in November $\left({ }^{\circ} \mathrm{C}\right)$ & 3.93 \\
\hline TMPSTDMX12 & Average total monthly precipitation in December $\left({ }^{\circ} \mathrm{C}\right)$ & 3.40 \\
\hline TMPSTDMN1 & Standard deviation for daily minimum air temperature in January $\left({ }^{\circ} \mathrm{C}\right)$ & 6.68 \\
\hline TMPSTDMN2 & Standard deviation for daily minimum air temperature in February $\left({ }^{\circ} \mathrm{C}\right)$ & 5.71 \\
\hline TMPSTDMN3 & Standard deviation for daily minimum air temperature in March $\left({ }^{\circ} \mathrm{C}\right)$ & 4.27 \\
\hline TMPSTDMN4 & Standard deviation for daily minimum air temperature in April $\left({ }^{\circ} \mathrm{C}\right)$ & 3.51 \\
\hline
\end{tabular}




\begin{tabular}{|c|c|c|}
\hline TMPSTDMN5 & Standard deviation for daily minimum air temperature in May $\left({ }^{\circ} \mathrm{C}\right)$ & 3.01 \\
\hline TMPSTDMN6 & Standard deviation for daily minimum air temperature in June $\left({ }^{\circ} \mathrm{C}\right)$ & 2.76 \\
\hline TMPSTDMN7 & Standard deviation for daily minimum air temperature in July $\left({ }^{\circ} \mathrm{C}\right)$ & 2.23 \\
\hline TMPSTDMN8 & Standard deviation for daily minimum air temperature in August $\left({ }^{\circ} \mathrm{C}\right)$ & 2.23 \\
\hline TMPSTDMN9 & Standard deviation for daily minimum air temperature in September $\left({ }^{\circ} \mathrm{C}\right)$ & 2.73 \\
\hline TMPSTDMN10 & Standard deviation for daily minimum air temperature in October $\left({ }^{\circ} \mathrm{C}\right)$ & 2.87 \\
\hline TMPSTDMN11 & Standard deviation for daily minimum air temperature in November $\left({ }^{\circ} \mathrm{C}\right)$ & 2.87 \\
\hline TMPSTDMN12 & Standard deviation for daily minimum air temperature in December $\left({ }^{\circ} \mathrm{C}\right)$ & 4.50 \\
\hline PCPMM1 & Average total monthly precipitation in January $(\mathrm{mm})$ & 210.50 \\
\hline PCPMM2 & Average total monthly precipitation in February $(\mathrm{mm})$ & 268.54 \\
\hline PCPMM3 & Average total monthly precipitation in March $(\mathrm{mm})$ & 328.70 \\
\hline PCPMM4 & Average total monthly precipitation in April (mm) & 357.50 \\
\hline PCPMM5 & Average total monthly precipitation in May (mm) & 201.30 \\
\hline PCPMM6 & Average total monthly precipitation in June ( $\mathrm{mm})$ & 54.20 \\
\hline PCPMM7 & Average total monthly precipitation in July (mm) & 33.04 \\
\hline PCPMM8 & Average total monthly precipitation in August (mm) & 29.25 \\
\hline PCPMM9 & Average total monthly precipitation in September $(\mathrm{mm})$ & 35.14 \\
\hline PCPMM10 & Average total monthly precipitation in October $(\mathrm{mm})$ & 141.43 \\
\hline PCPMM11 & Average total monthly precipitation in November $(\mathrm{mm})$ & 243.96 \\
\hline PCPMM12 & Average total monthly precipitation in December $(\mathrm{mm})$ & 210.32 \\
\hline PCPD1 & Average number of days of precipitation in January & 20.80 \\
\hline PCPD2 & Average number of days of precipitation in February & 19.41 \\
\hline PCPD3 & Average number of days of precipitation in March & 18.89 \\
\hline PCPD4 & Average number of days of precipitation in April & 17.07 \\
\hline PCPD5 & Average number of days of precipitation in May & 13.69 \\
\hline PCPD6 & Average number of days of precipitation in June & 5.98 \\
\hline PCPD7 & Average number of days of precipitation in July & 4.07 \\
\hline PCPD8 & Average number of days of precipitation in August & 4.36 \\
\hline PCPD9 & Average number of days of precipitation in September & 4.83 \\
\hline PCPD10 & Average number of days of precipitation in October & 9.56 \\
\hline PCPD11 & Average number of days of precipitation in November & 15.60 \\
\hline PCPD12 & Average number of days of precipitation in December & 19.87 \\
\hline SOLARAV1 & Average daily solar radiation for January (MJ/m2/day) & 11.50 \\
\hline SOLARAV2 & Average daily solar radiation for February (MJ/m2/day) & 15.42 \\
\hline SOLARAV3 & Average daily solar radiation for March (MJ/m2/day) & 20.83 \\
\hline SOLARAV4 & Average daily solar radiation for April (MJ/m2/day) & 25.04 \\
\hline SOLARAV5 & Average daily solar radiation for May (MJ/m2/day) & 28.95 \\
\hline SOLARAV6 & Average daily solar radiation for June (MJ/m2/day) & 32.08 \\
\hline SOLARAV7 & Average daily solar radiation for July (MJ/m2/day) & 30.93 \\
\hline SOLARAV8 & Average daily solar radiation for August (MJ/m2/day) & 28.12 \\
\hline SOLARAV9 & Average daily solar radiation for September $(\mathrm{MJ} / \mathrm{m} 2 /$ day $)$ & 23.99 \\
\hline SOLARAV10 & Average daily solar radiation for October $(\mathrm{MJ} / \mathrm{m} 2 /$ day) & 17.73 \\
\hline SOLARAV11 & Average daily solar radiation for November $(\mathrm{MJ} / \mathrm{m} 2 /$ day $)$ & 12.37 \\
\hline SOLARAV12 & Average daily solar radiation for December (MJ/m2/day) & 10.14 \\
\hline DEWPT1 & Average daily dew point temperature for January $\left({ }^{\circ} \mathrm{C}\right)$ & -8.69 \\
\hline
\end{tabular}




\begin{tabular}{c|c|c}
\hline DEWPT2 & Average daily dew point temperature for February $\left({ }^{\circ} \mathrm{C}\right)$ & -6.53 \\
\hline DEWPT3 & Average daily dew point temperature for March $\left({ }^{\circ} \mathrm{C}\right)$ & -5.16 \\
\hline DEWPT4 & Average daily dew point temperature for April $\left({ }^{\circ} \mathrm{C}\right)$ & -2.08 \\
\hline DEWPT5 & Average daily dew point temperature for May $\left({ }^{\circ} \mathrm{C}\right)$ & -0.60 \\
\hline DEWPT6 & Average daily dew point temperature for June $\left({ }^{\circ} \mathrm{C}\right)$ & 0.65 \\
\hline DEWPT7 & Average daily dew point temperature for July $\left({ }^{\circ} \mathrm{C}\right)$ & 4.47 \\
\hline DEWPT8 & Average daily dew point temperature for August $\left({ }^{\circ} \mathrm{C}\right)$ & 3.64 \\
\hline DEWPT9 & Average daily dew point temperature for September $\left({ }^{\circ} \mathrm{C}\right)$ & -0.09 \\
\hline DEWPT10 & Average daily dew point temperature for October $\left({ }^{\circ} \mathrm{C}\right)$ & -1.68 \\
\hline DEWPT11 & Average daily dew point temperature for November $\left({ }^{\circ} \mathrm{C}\right)$ & -3.92 \\
\hline DEWPT12 & Average daily dew point temperature for December $\left({ }^{\circ} \mathrm{C}\right)$ & -6.88 \\
\hline WNDAV1 & Average daily wind speed in January $(\mathrm{m} / \mathrm{s})$ & 2.30 \\
\hline WNDAV2 & Average daily wind speed in February $(\mathrm{m} / \mathrm{s})$ & 2.65 \\
\hline WNDAV3 & Average daily wind speed in March $(\mathrm{m} / \mathrm{s})$ & 3.01 \\
\hline WNDAV4 & Average daily wind speed in April $(\mathrm{m} / \mathrm{s})$ & 3.23 \\
\hline WNDAV5 & Average daily wind speed in May $(\mathrm{m} / \mathrm{s})$ & 3.31 \\
\hline WNDAV6 & Average daily wind speed in June $(\mathrm{m} / \mathrm{s})$ & 3.22 \\
\hline WNDAV7 & Average daily wind speed in July $(\mathrm{m} / \mathrm{s})$ & 2.98 \\
\hline WNDAV8 & Average daily wind speed in August $(\mathrm{m} / \mathrm{s})$ & 2.74 \\
\hline WNDAV9 & Average daily wind speed in September $(\mathrm{m} / \mathrm{s})$ & 2.70 \\
\hline WNDAV10 & Average daily wind speed in October $(\mathrm{m} / \mathrm{s})$ & 2.57 \\
\hline WNDAV11 & Average daily wind speed in November $(\mathrm{m} / \mathrm{s})$ & 2.31 \\
\hline WNDAV12 & Average daily wind speed in December $(\mathrm{m} / \mathrm{s})$ & 2.33 \\
\hline & &
\end{tabular}

